Annals of Warsaw University of Life Sciences - SGGW

Land Reclamation No 48 (2), 2016: 99-109

(Ann. Warsaw Univ. Life Sci. - SGGW, Land Reclam. 48 (2), 2016)

\title{
Turbulent intensity and scales of turbulence after hydraulic jump in rectangular channel
}

\author{
ADAM KOZIOŁ, JANUSZ URBAŃSKI, ADAM KICZKO, MARCIN KRUKOWSKI, \\ PIOTR SIWICKI \\ Department of Hydraulic Engineering, Warsaw University of Life Sciences - SGGW
}

\begin{abstract}
Turbulent intensity and scales of turbulence after hydraulic jump in rectangular channel. Experimental research was undertaken to investigate the changes in spatial turbulence intensity and scales of turbulent eddies (macroeddies) in a rectangular channel and the influence of the hydraulic jump on vertical, lateral and streamwise distributions of relative turbulence intensity and scales of turbulent eddies. The results of three tests for different discharges are presented. An intensive turbulent mixing that arises as a result of a hydraulic jump has a significant effect on instantaneous velocity, turbulent intensities and sizes of eddies, as well as their vertical and longitudinal distributions. In the analysed case the most noticeable changes appeared up to $0.5 \mathrm{~m}$ downstream the hydraulic jump. In the vertical dimension such an effect was especially seen near the surface. The smallest streamwise sizes of macroeddies were present near the surface, maximum at the depth of $z / h=0.6$ and from that point sizes were decreasing towards the bottom. The intensive turbulent mixing within the hydraulic jump generates macroeddies of small sizes.
\end{abstract}

Key words: turbulent intensity, eddies, hydraulic jump, sluice gate, rectangular channel

\section{INTRODUCTION}

The design of any water structure in open channels requires knowledge on a kinematic and dynamic structure of a stream. The turbulence is one of the most essential phenomenon that determines processes occurring in flowing water. Turbulent flow manifests with a chaotic and intensive mixing of water masses, with changing velocity. The investigations of the turbulence properties is necessary for understanding of processes such as: the exchange of mass and momentum between these parts of the channel that have diversified velocities, the transport capacity of the stream, sediment transport and redeposition, bed formation, contaminant transport and the whole cross-sectional discharge capacity.

A hydraulic jump that is often formed downstream hydraulic structures, it is characterized by an intensive turbulent mixing. It manifests with an increased velocity at a bottom and pulsation velocity of the stream, with a strong erosion potential, especially for non-cohesive soils. A stream of water entrains soil particles and transports them leading to development of scour holes. The erosion properties of a stream comes from its complex kinematic structure of the intensive turbulent flow. These depend on a construction of hydraulic structures, especially energy dissipation devices, outlet design and a submergence of the 
hydraulic jump. There exist a rich body of literature on this topic.

As previous studies revolved (Kumin 1956, Kališ 1961, Wu and Rajaratnam 1996, Urbański 2006, Guan et al. 2014), turbulence intensity and velocity at the bottom decrease with a distance from the hydraulic jump. However, just after a stilling section, because of its limited length, a stream turbulence is still high what intensifies an erosion downstream and might lead to the development of scour. It is not desirable from the viewpoint of maintaining the stability of the riverbed and the structure itself.

Open channel flow is, by nature, three-dimensional. Even in a straight laboratory channel, turbulence can cause instantaneous velocities: $u_{i}, v_{i}$ and $w_{i}$. The turbulence intensity is one of the most important characteristics of turbulent water flow, being defined in all three directions by the velocity components as follows:

$$
u^{\prime}=\sigma_{x}=\sqrt{u^{2}}, \quad v^{\prime}=\sigma_{y}=\sqrt{v^{2}}, \quad w^{\prime}=\sigma_{z}=\sqrt{\overline{w^{2}}}
$$

where $x, y$ and $z$ are streamwise, lateral, and vertical directions, respectively. The intensity can be also defined in a nondimensional form of the relative turbulence intensity given by $u^{\prime} / U, v^{\prime} / U$, and $w^{\prime} / U$, where $U$ is the time-averaged point velocity in the $x$ direction. In this paper we took advantage of the second definition. Nezu and Nakagawa (1993) proposed the equations describing relative turbulence intensity distributions in single channels for steady two-dimensional flow. However, the conditions of water flow in a single channel or a compound channel with submerged and emergent vegetation and after a water structure are significantly different and very complex (Shiono and Knight 1991, Tominaga and Nezu 1991, Nezu and Nakagawa 1993, Nikora et al. 1994, Rowiński et al. 1998, 2002, Babaeyan-Koopaei et al. 2002, Dargahi 2003, Czernuszenko et al. 2007, Mazurczyk 2007, Yang et al. 2007, Nepf and Ghisalberti 2008, Siniscalchi 2012, Pagliara and Palermo 2013, Kozioł 2013, 2015).

The mechanism of the turbulence is associated with generation of big scale vortices, from which the turbulent energy is transformed into energy cascade for smaller scale eddies until it is dissipated into heat by the molecular viscosity (Nezu and Nakagawa 1993). The largest scale eddies are considered as macroeddies. They are impermanent and disintegrate into structures of smaller sizes (microeddies), but simultaneously new, large structures are generated. As the result, the flow field consists of eddies of different scales. The information on eddies scales allows characterizing the phenomenon of the turbulence, that is crucial for determining such river processes as sediment transport and deposition, bed formation and others.

The sizes of macroeddies determine the external scale of turbulence. Determination of macroeddies sizes requires identification of eddies time-scale. This is achieved on the basis of an autocorrelation function $-R(t)$. The function exhibits similar forms of decaying curves with an alteration of the domains of the positive and negative values. With the autocorrelation function Euler time-macroscales $\left(T_{E}\right)$ are derived according to (Nikora et al. 1994): 
$T_{E}=\int_{0}^{\infty} R(t) d t$

which are the measure of the slowest changes in the turbulent flow caused by macroeddies. According to the Taylor hypothesis for a steady and uniform turbulent flow, when mean velocity in a given point significantly exceeds the velocity of fluctuations, there exists a direct relationship of temporal $\left(T_{E}\right)$ and spatial Eulerian $(L)$ autocorrelation functions. Referring to Taylor's relationships between the $L$ and the $T_{E}$ turbulence macroscale, the following formula for mean streamwise sizes can be derived:

$L=U T_{E}$

In studies on the turbulence, the sizes of macroeddies are often normalized with the water depths $(h)$ for the sake of an easier comparison. Macroeddies in single and compound channels without and with vegetation were previously analysed by: Nikora et al. (1994), Kozioł (2000, 2008, 2015), Rowiński et al. (2002), Rowiński and Mazurczyk (2006), Czernuszenko et al. (2007) and Mazurczyk (2007).

The size of microeddies is the other measure characterizing the turbulence. It accounts for a size of the smallest eddies, present in the flowing water. Kolmogoroff and Taylor proposed spatial scales of microeddies (Nezu and Nakagawa 1993, Mazurczyk 2007, Kozioł 2012, 2015). The Taylor microscale depends both on the macroscopic motion by means of the fluctuating velocity and on dissipative characteristics, whereas the Kolmogoroff microscale depends only on dissipative and viscous characteristics (Nezu and Nakagawa 1993). The sizes of microeddies are smaller by few orders of magnitude than a mean velocity (Kozioł 2015) or the scale of macroeddies. Because of their small values, being of order of decimal parts of a millimetre, it is difficult to draw conclusions about significant changes of their values, therefore they were not analysed in this paper.

This paper presents the analysis of the relative turbulence intensity and spatial scales of turbulence (macroeddies) distributions on length of stream below a stilling basin, calculated basing on the measurements of instantaneous water velocities in a rectangular channel. Instantaneous velocities of water in streamwise and lateral direction were measured in centerline of the channel, over a flat and horizontal bed and three tests were taken for different flows. The used measuring data come from with earlier investigations of relating lengths of protection and the scour of bed (Urbański 2006, 2012).

\section{EXPERIMENTAL SETUP AND PROCEDURE}

The experiments considered herein were carried out in the Hydraulic Laboratory of the Department of Hydraulic Engineering, Faculty of Civil and Environmental Engineering at the Warsaw University of Sciences - SGGW. Laboratory experiments were performed for a weir model built in a rectangular channel, wide for $1 \mathrm{~m}$. The diagram of the experimental setup is shown in Figure 1. It consists of the sluice gate, stilling base and a section 
of reinforced bottom, as a transitional region. The sluice gate allowed maintaining a certain water depth at the upstream side, while a gate placed at the channel end, ensures the stabilization of the stream depth $(h)$ in the downstream sections. The stream flow rate $(q)$, per unit, was fixed during each experiment. Values of gate opening height $(a)$ are given in Table. The submerged hydraulic jump was formed and maintained in the stilling basin. Hydraulic flow conditions of experiments including properties of the hydraulic jump: discharge $(Q)$, unit discharge $(q)$, tailwater depth $(h)$, upstream depth $(H)$, gate opening $(a)$, calculated supercritical $\left(h_{1}\right)$ and $\left(h_{2}\right)$ subcritical depths, and supercritical Froude number $F r_{1}=U_{a} /(g a)^{1 / 2}$ (where $U_{a}=Q /(b a)$ is the supercritical approach velocity, $b$ is the width of gate, $g$ is the acceleration due to gravity, are given in Table). More detailed information's about the methodology are found in the papers Urbański (2006, 2012).

During experiments the velocity profiles were taken over the sandy and horizontal bed in the axial plane of the channel starting from the end of the reinforced reach (Fig. 1). The measurements of instantaneous velocities were carried out at 16 verticals. Each profile consisted of four depth points arranged as follows: the bottom $z_{1}=0.018 \mathrm{~m}, z_{2}=$ $=0.3 h, z_{3}=0.6 h$ and just below the water surface $z_{4}=h-0.02 \mathrm{~m}$.

In the study instantaneous streamwise $u_{i}$ and lateral $v_{i}$ velocities were measured with the use of the programmable electromagnetic liquid velocity meter PEMS manufactured by Delft Hydraulics. The meter proved to yield a good description of the turbulence characteristics when certain conditions related to the flow it-

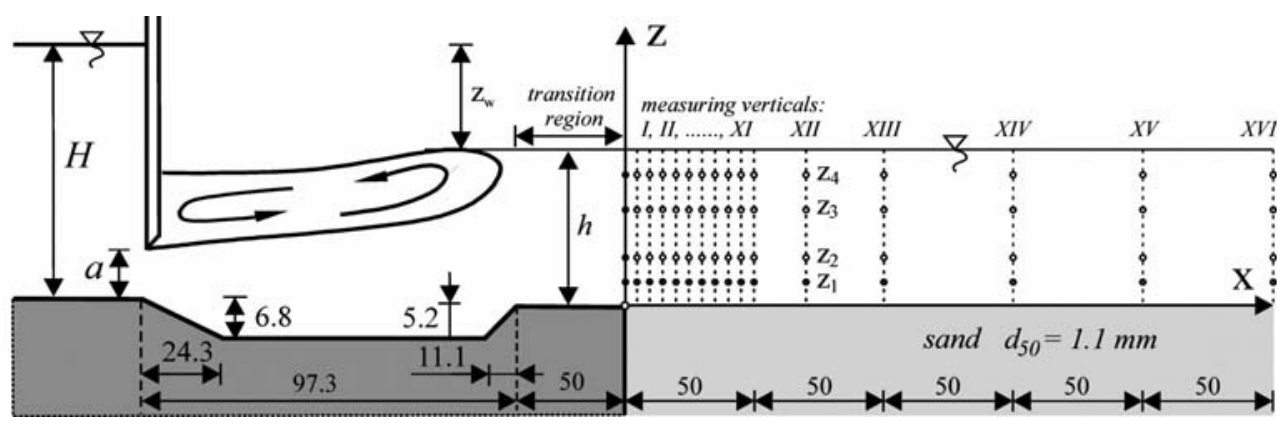

FIGURE 1. Schema of investigated model and base dimensions (dimensions in $\mathrm{cm}$ )

TABLE. The hydraulic parameters of flow during of experiments

\begin{tabular}{|c|c|c|c|c|c|c|c|c|}
\hline \multirow{2}{*}{ Test } & $Q$ & $q$ & $h$ & $H$ & $a$ & $h_{1}$ & $h_{2}$ & $F r_{1}$ \\
\cline { 2 - 8 } & $\mathrm{m}^{3} \cdot \mathrm{s}^{-1}$ & $\mathrm{~m}^{2} \cdot \mathrm{s}^{-1}$ & $\mathrm{~m}$ & $\mathrm{~m}$ & $\mathrm{~m}$ & $\mathrm{~m}$ & $\mathrm{~m}$ & - \\
\hline 1 & 0.049 & 0.049 & 0.133 & 0.417 & 0.032 & 0.020 & 0.148 & 2.73 \\
\hline 2 & 0.073 & 0.073 & 0.165 & 0.445 & 0.049 & 0.030 & 0.175 & 2.15 \\
\hline 3 & 0.097 & 0.097 & 0.193 & 0.462 & 0.064 & 0.040 & 0.201 & 1.87 \\
\hline
\end{tabular}


self and the configuration of the instrument were satisfied (Buffin-Bélanger and Roy 2005). The measurements were conducted with a maximum frequency of $10 \mathrm{~Hz}$ in the velocity range of $0-1 \mathrm{~m} / \mathrm{s}$ with an accuracy of $\pm 0.01 \mathrm{~m} / \mathrm{s}$. A sampling duration of $120 \mathrm{~s}$ was determined from initial tests to be adequate to obtain stationary turbulence statistics and therefore, was used. Buffin-Bélanger and Roy (2005) report that, for most turbulent statistics, a sufficient record length for the measurements is $60-90 \mathrm{~s}$. In cases of our experiments, even longer time series were recorded to provide reliability of data and constancy of higher-order velocity moments. The measured velocity field was obviously of a stochastic nature and the stationarity and ergodicity of the process was checked.

\section{RESULTS AND ANALYSIS}

\section{Velocity profiles}

Figure 2 presents the changes of streamwise velocities $-U$, with the relative depth $-z / h(z$ is the distance from the measurement point to the bed surface, $h$ is the water depth) on the length of a stream $(x)$ after the hydraulic jump and the transition region (Fig. 1). Downstream the hydraulic jump distribution at a depth of streamwise velocities diverged from typical shapes in open channels. Velocity profiles changed with a length of stream what is especially visible for flows with larger depths (test 3, Fig. 2). The lowest streamwise velocities were observed near the water surface, while the highest close to the bottom. It is a result of the velocity distribution in the hydraulic jump (backward flow near the water surface). With the increasing distance from the jump the maximum velocity was shifted from the bottom towards the surface, it results in an increase of velocity near the surface, and its decrease at the bottom, which is typical for the so-called transition section for the flow of the hydraulic jump (Wu and Rajaratnam 1996). In the present experiment in a distance of $x / h=1.5$ the velocity distribution became similar to the observed one in open channels. On the basis of the results of Urbański (2012) and present ones, it can be stated that a distance downstream of the hydraulic jump, that is needed for a development of

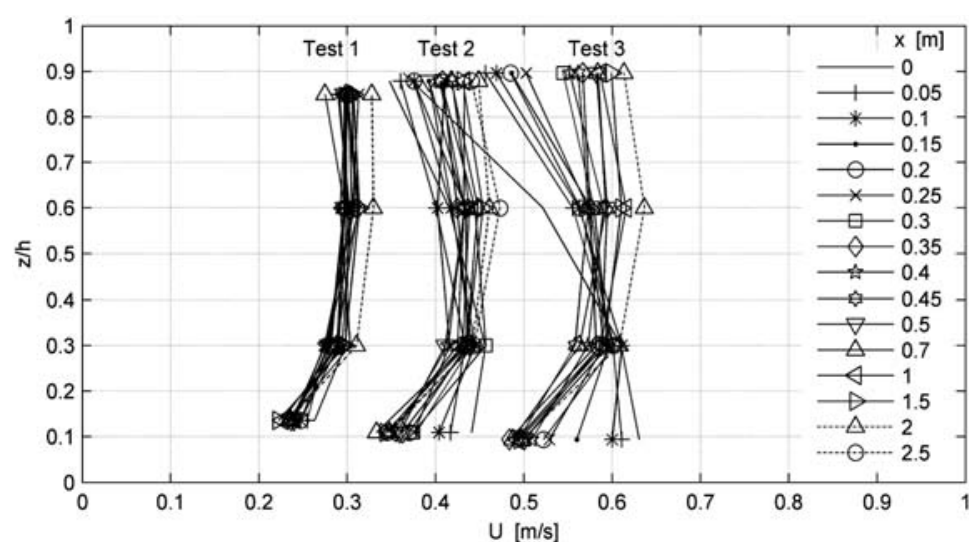

FIGURE 2. Vertical profiles of streamwise velocities below a stilling basin for three tests 
the typical open-channel configuration of the velocity profile depends on the properties of the hydraulic jump and the flow depth $(h)$ in the lower stand.

\section{Distribution of turbulence intensities}

Figure 3 presents the vertical distributions of streamwise relative turbulence intensity after the hydraulic jump for three tests. The highest relative intensity of turbulence in the vertical occurred at the water surface, decreasing towards the bottom, and became constant after reaching the depth of $z / h=0.6$. Maximum intensities occurred next to hydrau- lic jump at a distance $x=0 \mathrm{~m}$. Figure 4 presents the streamwise distributions of relative turbulence intensities along the stream below the stilling basin for $z / h=$ $=0.1-0.9$. The most significant decline in the relative intensity of turbulence took place next to the jump at a distance $x=$ $=0-0.5 \mathrm{~m}$, farther downstream its values remained nearly constant. For smaller flow rates, at a distance $x>0.5 \mathrm{~m}$ relative intensity of turbulence was larger at the water surface $(z / h=0.85$, test 1 , Fig. 4$)$.

In single and compound channels, for free flow conditions, streamwise turbulence intensities increase from the water surface towards the bottom
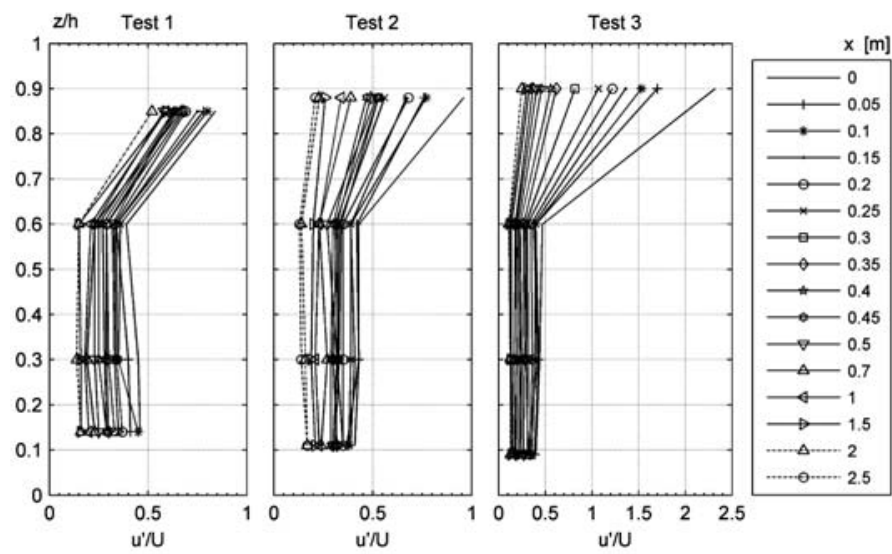

FIGURE 3. Vertical distributions of relative turbulence intensities for three tests

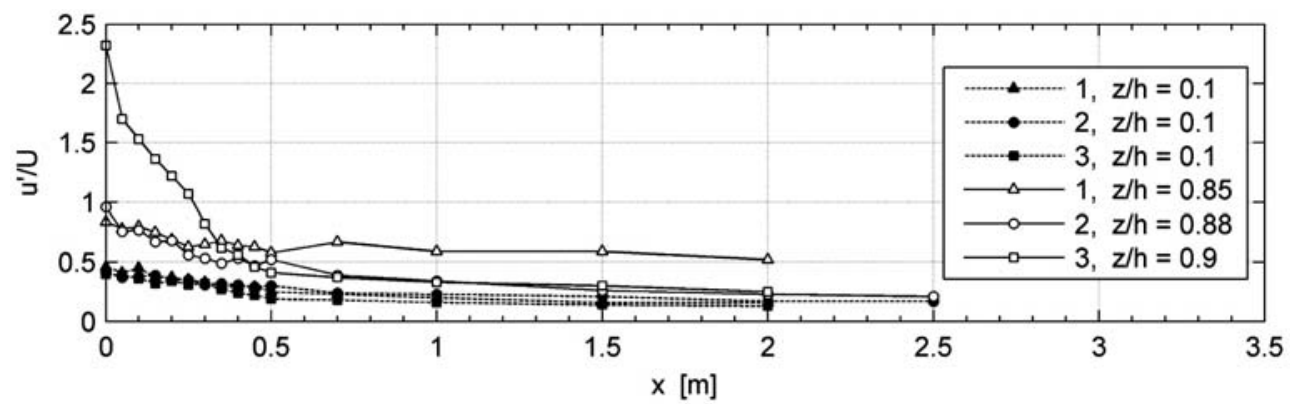

FIGURE 4. Streamwise distributions of relative turbulence intensities in the $x$ direction below the hydraulic jump for $z / h=0.1-0.9$ 
(Nikora et al. 1994, Kozioł 2013). In the present study for the farthest measurement points the distribution of the streamwise turbulence intensity was different. Its values decreased from the water surface or remain constant along the depth (Fig. 3), so are different from these presented by Nezu and Nakagawa (1993) for single channels. However, the range of the acquired values for farthest profiles: $u^{\prime} / U=0.05-0.2$ was close to these reported in the literature for the open channels with the free flow (Czernuszenko and Lebiecki 1980, Nikora 1985, Shiono and Knight 1991, Nikora et al. 1994, Nikora and Smart 1997, Rowiński et al. 2002, Rowiński and Mazurczyk 2006, Sanjou et al. 2010, Kozioł 2013).

Figure 5 presents the vertical distributions of relative velocities and turbulence of the turbulence in the streamwise and lateral directions were constant and did not change with the length of the stream. Just downstream the hydraulic jump ( $x=$ $=0 \mathrm{~m})$ near the water surface $(z / h=0.9)$ relative intensities of turbulence in both directions were the same, while below $z / h \leq 0.6$ the streamwise direction dominated. At a distance of the hydraulic jump, at the water surface the lateral turbulence intensity was lower than the streamwise one but toward the bottom $(z / h \leq 0.6)$ the intensities became equal (Fig. 5).

It can be noted that the greatest changes in the turbulence intensity occurred downstream the hydraulic jump at the distance $x=0-0.5 \mathrm{~m}$, while vertically near the water surface. These changes resulted from an intensive mixing of the downstream the hydraulic jump, especially at the water surface.
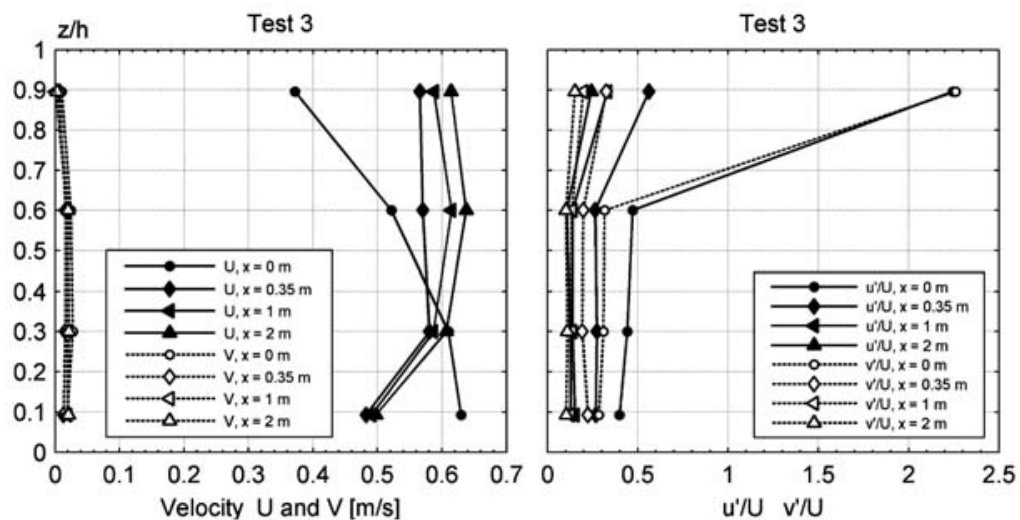

FIGURE 5. Vertical distributions of velocities and relative turbulence intensities in streamwise and lateral direction for four verticals in test 3

intensities in streamwise and lateral direction for four verticals in test 3 . The averaged cross-sectional velocity $(V)$ was almost constant at depth and its value was small compared to the streamwise vertical velocity. Profiles of the relative intensity

\section{Spatial scales of turbulent eddies (macroeddies)}

Figure 6 presents the vertical distributions of streamwise relative sizes of macroeddies for three tests. The results suggest that regardless of the flow rate 

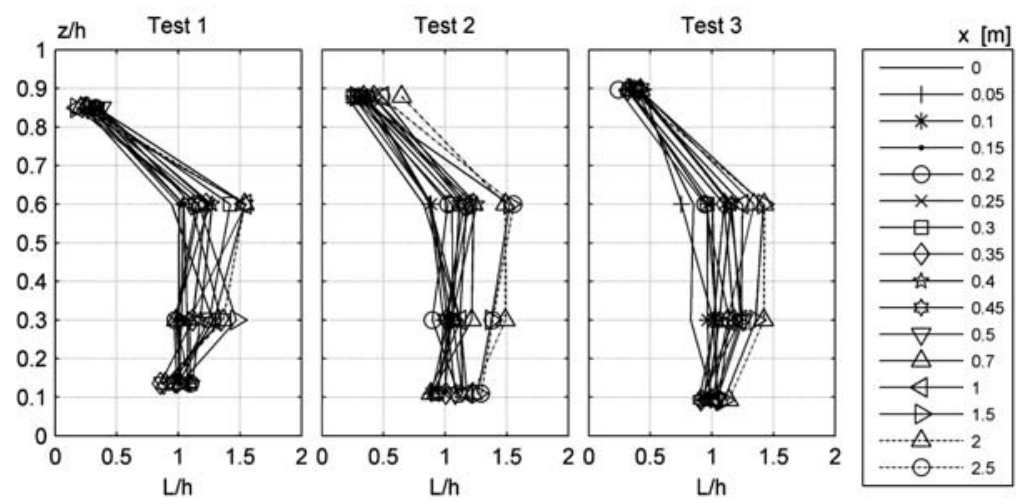

FIGURE 6. Vertical distributions of relative sizes of macroeddies for three tests

downstream the hydraulic jump the vertical distributions of relative sizes of macroeddies are equal. The smallest relative sizes of macroeddies in vertical direction appeared at the water surface $(L / h=$ $=0.2-0.6$ ), increased to the relative depth of $z / h=0.6$, and then decreased towards the bottom to the length of $L / h=0.9-1.3$. The intense turbulent mixing in the hydraulic jump formed only small sized macroeddies downstream. In the stream centre $(z / h=0.3-0.6$, Fig. 6$)$ the relative sizes of macroeddies were greater due to the presence of the highest gradients of mean velocity and high turbulence region near the water surface combined with fluctuations of the water surface.
All acquired values of the relative sizes of macroeddies $L / h$ were in the range from 0.2 to 1.6 and are also comparable with those found in the literature for a single and a compound channel: from 0.1 to a few depth of the stream (Nikora et al. 1994, Rowiński et al. 2002, Rowiński and Mazurczyk 2006, Czernuszenko et al. 2007, Mazurczyk 2007 and Kozioł 2000, 2008 and 2015).

Figure 7 presents the distributions of relative sizes of macroeddies along the stream after the hydraulic jump for $z / h=0.6-0.9$. At water surface and near the bed relative sizes of macroeddies did not change on the length of the stream (Figs 6 and 7). However, in the centre of

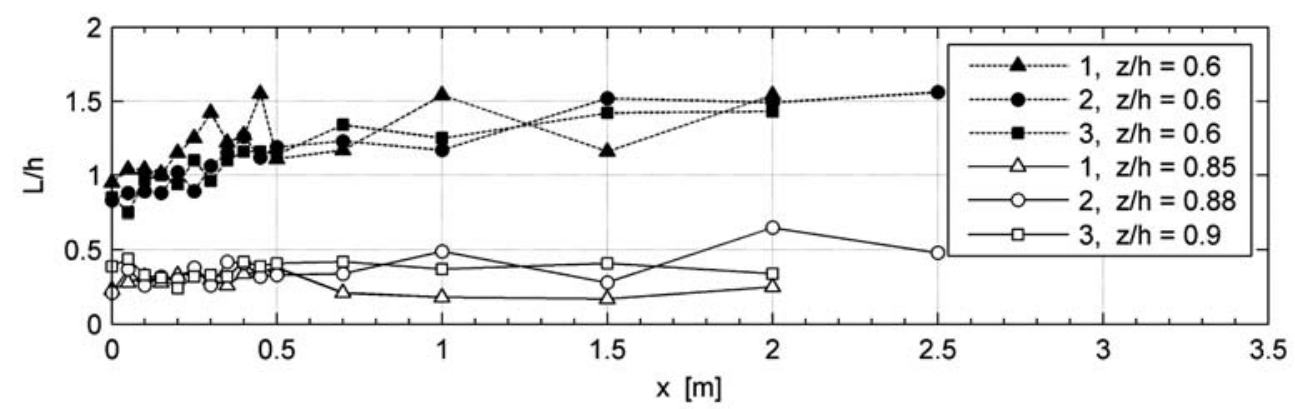

FIGURE 7. Distributions of relative sizes of macroeddies on length of stream after the hydraulic jump for $z / h=0.6-0.9$ 
the stream $(z / h=0.6$, Fig. 7), the relative sizes of macroeddies slightly grew at a distance $x=0-0.5 \mathrm{~m}$ from the hydraulic jump and further downstream remained constant.

As it can be seen in Figures 6 and 7 an intensive turbulent mixing caused by the hydraulic jump had a large impact on the relative sizes of macroeddies and their vertical and longitudinal distributions. The biggest changes were just downstream the hydraulic rebound $(x=$ $=0-0.5 \mathrm{~m})$ and vertically near the water surface.

\section{CONCLUSIONS}

Investigations of relative turbulence intensity and the streamwise sizes of macroeddies, presented in the paper, are based on measurements of instantaneous velocities $\left(u_{i}\right.$ and $\left.v_{i}\right)$ after the hydraulic jump in a hydraulic laboratory, in a rectangular channel with a flat and horizontal bed. The effect of the hydraulic jump is considerably high and it influences most of the turbulence characteristics in the channel.

The intensive turbulent mixing caused by the hydraulic jump had a large impact on the instantaneous velocity, turbulence intensity and sizes of macroeddies, as well as their vertical and streamwise distributions in the stream. The largest changes occurred just behind the hydraulic jump $(x=0-0.5 \mathrm{~m})$, while vertically near the water surface. The lateral velocity $(V)$ was almost constant in the depth and its values were relatively small compared to the streamwise velocity $(U)$. The vertical profiles of the relative intensity of turbulence in the streamwise and lateral di- rections were similar and did not change with the length of the stream.

Regardless of the flow rate the vertical profiles of the relative sizes of macroeddies had the same shape. The smallest relative sizes of macroeddies in the vertical profile were present at the water surface $(L / h=0.2-0.6)$, rising to the relative depth $z / h=0.6$, and then decreasing towards the bottom to the value of $L / h=$ $=0.9-1.3$. The intense turbulent mixing in the hydraulic jump led to the formation of only small sizes of macroeddies downstream. The calculated streamwise sizes of macroeddies $(L / h=0.2-1.6)$ were similar in comparison with the sizes of macroeddies in an open channel $(L / h=$ $=0.1-4.4$, Nikora et al. 1994, Rowiński et al. 2002, Kozioł 2015). Measured turbulence characteristic are significantly different from the types of distributions in open channels.

The study presented characteristics of the turbulence downstream the hydraulic jump over a flat and horizontal bed, before the formation of scour. The impact of a high turbulence stream (especially downstream a water structure) on the bottom is the direct cause of formation of score structures downstream water structures. To complete the picture of turbulence characteristics downstream the hydraulic jump detailed information about their distributions in vertical and longitudinal directions within and above scour should be also provided. Such a problem will be the scope of a separate publication.

\section{REFERENCES}

BABAEYAN-KOOPAEI K., ERVINE D.A., CARLING P.A., CAO Z. 2002): Velocity and turbulence measurements 
for two overbank flow events in River Severn. J. Hydraul. Eng. ASCE 128, 10, 891-900. DOI: 10.1061/(ASCE)07339429(2002)128:10(891).

BUFFIN-BÉLANGER T., ROY A.G. 2005: $1 \mathrm{~min}$ in the life of a river: Selecting the optimal record length for the measurement of turbulence in fluvial boundary layers. Geomorphology 68, 1-2, 77-94.

CZERNUSZENKO W., LEBIECKI P. 1980: Turbulent characteristics of stream in open channel. Archiwum Hydrotech. 27, 1, 19-38 (in Polish).

CZERNUSZENKO W., KOZIOE A., ROWIŃSKI P.M. 2007: Measurements of 3D Turbulence Structure in a Compound Channel. Archives of Hydro-Engineering and Environmental Mechanics, Institute of Hydro-Engineering PAS 54, 1, 3-21.

DARGAHI B. 2003: Scour development downstream of a spillway. J. Hydraul. Res., 41, 4, 417-426. DOI: 10.1080/002 21680309499986.

GUAN D., MELVILLE B.W., FRIEDRICH H. 2014: Flow Patterns and Turbulence Structures in a Scour Hole Downstream of a Submerged Weir. Journal of $\mathrm{Hy}$ draulic Eng. ASCE 140, 1, 68-76. DOI: 10.1061/(ASCE)HY.1943-7900.0000803.

KALIŠ J. 1961: Diminution de la turbulence derriere le ressaut. Raport 111 IX Congres de IAHR, Dubrovnik.

KOZIOŁ A.P. 2000: Longitudinal sizes of the largest eddies in the compound channel. Prz. Nauk. Inż. Kszt. Środ. 18, 151-159 (in Polish).

KOZIOŁ A.P. 2008: Investigation of the time and spatial macro-scale of turbulence in a compound channel. Acta Sci. Pol., Arch. 7, 4, 15-23 (in Polish).

KOZIOŁ A.P. 2012: The Kolmogorov's microscale eddies in a compound channel. Ann. Warsaw Univ. Life Sci. - SGGW, Land Reclam. 44, 2, 121-132. DOI: 10.2478/v10060-011-0068-7.

KOZIOŁ A.P. 2013: Three-dimensional turbulence intensity in a compound channel. J. Hydraul. Eng. 139, 8, 852-864. DOI: 10.1061/(ASCE)HY.1943-7900.0000739.
KOZIOŁ A. 2015: Scales of Turbulence in Compound Channels. Acta Geophys. 63, 2, 514-532. DOI: $10.2478 / \mathrm{s} 11600-014-$ 0247-0.

KUMIN D.I. 1956: Turbulentnost i gaszenie energii pri sopraženi b'efow. Izviestia VNIIG 55.

MAZURCZYK A. 2007: Scales of turbulence in compound channels with trees on floodplains. Publs. Inst. Geophys. Pol. Acad. Sc. E-7, 401, 169-176.

NEPF H., GHISALBERTI M. 2008: Flow and transport in channels with submerged vegetation. Acta Geophys. 56, 3, 753-777. DOI: 10.2478/s11600-008-0017-y.

NEZU I., NAKAGAWA H. 1993: Turbulence in Open-Channel Flows. IAHR Monographs. Balkema, Rotterdam.

NIKORA V.I. 1985: On the turbulence structure of river flows with sand wave bottom. Meteorol. Gidrol. 6, 98-103.

NIKORA V.I. 1999: Origin of the " -1 " spectral law in wall-bounded turbulence. Phys. Rev. Lett. 83, 4, 734-736. DOI: 10.1103/PhysRevLett.83.734.

NIKORA V.I., ROWIŃSKI P., SUKHODOLOV A., KRASUSKI D. 1994: Structure of river turbulence behind warm-water discharge. J. Hydraul. Eng. 120, 2, 191-208. DOI: 10.1061/(ASCE)07339429(1994)120:2(191).

NIKORA V.I., SMART G.M. 1997: Turbulence characteristics of New Zealand gravel-bed rivers. J. Hydraul. Eng. 123, 9, 764-773. DOI: 10.1061/(ASCE)07339429(1997)123:9(764).

PAGLIARA S., PALERMO M. 2013: Rock Grade Control Structures and Stepped Gabion Weirs: Scour Analysis and Flow Features. Acta Geophys. 61, 126-150. DOI: $10.2478 / \mathrm{s} 11600-012-0066-0$.

ROWIŃSKI P.M., MAZURCZYK A. 2006: Turbulent characteristics of flows through emergent vegetation. Proc. Int. Conf. on Fluvial Hydraulics "River Flow 2006", 6-8 September 2006, Lisbon, Portugal, 623-630.

ROWIŃSKI P.M., CZERNUSZENKO W., KOZIOŁ A.P., KUBRAK J. 2002: Prop- 
erties of a streamwise turbulent flow field in an open two-stage channel. Arch. Hydro-Eng. Environ. Mech. 49, 2, 37-57.

ROWIŃSKI P., CZERNUSZENKO W., KOZIOŁ A., KUŚMIERCZUK K., KUBRAK J. 1998: Longitudinal turbulence characteristics in a compound channel under various roughness conditions. Proc. 3rd Int. Conf. on Hydro-Science and Engineering, Cottbus/Berlin, Germany.

SANJOU M., NEZU I., SUZUKI S., ITAI K. 2010: Turbulence structure of compound open-channel flows with one-line emergent vegetation. J. Hydrodyn. B 22, 5, Suppl. 1, 577-581. DOI: 10.1016/S10016058(09)60255-9.

SHIONO K., KNIGHT D.W. 1991: Turbulent open-channel flows with variable depth across the channel. J. Fluid Mech. 222, 7, 617-646. DOI: 10.1017/ S0022112091001246.

SINISCALCHI F., NIKORA V.I., ABERLE J. 2012: Plant patch hydrodynamics in streams: Mean flow, turbulence, and drag forces. Water Resour. Res. 48, W01513. DOI: 10.1029/2011WR011050.

TOMINAGA A., NEZU I. 1991: Turbulent structure in compound open-channel flows. J. Hydraul. Eng. 117, 1, 21-41.

URBAŃSKI J. 2006: Investigation of turbulence intensity of stream below hydraulic jump on the dam model. In: Problemy Hydrotechniki - Modelowanie i hydroinformatyka oraz wybrane zagadnienia ochrony przeciwpowodziowej. Dolnośląskie Wydawnictwo Edukacyjne, Wrocław, 363-370 (in Polish).

URBAŃSKI J. 2012: Verification of criteria for determining the length of bed protection in downstream of the weir. Scientific Review - Engineering and Environmental Sciences 55, 18-26 (in Polish).

WU S., RAJARATNAM N. 1996: Transition from hydraulic jump to open channel flow. J. Hydraul. Eng. 122, 9, 526-528.
YANGK.,CAOS. KNIGHTD.W.2007:Flow patterns in a compound channels with vegetated floodplains J. Hydraul. Eng. 133, 2, 148-159. DOI: 10.1061/(ASCE)07339429(2007)133:2(148).

Streszczenie: Intensywność turbulencji $i$ skale turbulencji po odskoku hydraulicznym $w$ prostokatnym korycie. Celem badań eksperymentalnych było wyznaczenie zmian przestrzennej intensywności turbulencji i skal turbulentnych wirów (makrowirów) w prostokątnym korycie oraz wpływu odskoku hydraulicznego na pionowe, poprzeczne i podłużne rozkłady względnej intensywności turbulencji i na skale turbulentnych wirów. $\mathrm{W}$ artykule przedstawiono wyniki dla trzech doświadczeń o różnych przepływach. Intensywne mieszanie strumienia wody spowodowane odskokiem hydraulicznym ma bardzo duży wpływ zarówno na wartości chwilowych prędkości, intensywności turbulencji i długości makrowirów, jak i na ich pionowe, podłużne $\mathrm{i}$ poprzeczne rozkłady $\mathrm{w}$ strumieniu. W analizowanym strumieniu największe zmiany charakterystyk występują tuż za odskokiem hydraulicznym, na odcinku o długości pół metra, natomiast w pionie przy zwierciadle wody. Najkrótsze podłużne względne długości makrowirów w pionie występują przy zwierciadle wody, rosną do względnej głębokości $z / h=0,6$, a następnie maleją w kierunku dna. Intensywne turbulentne mieszanie strumienia wody w odskoku hydraulicznym doprowadziło do tworzenia się tylko małych makrowirów. Pomierzone charakterystyki turbulencji znacznie różnią się od typowych rozkładów w korytach otwartych.

\section{MS received February 2016}

\section{Authors address:}

Adam P. Kozioł

Katedra Inżynierii Wodnej

Wydział Budownictwa i Inżynierii Środowiska SGGW

ul. Nowoursynowska 166

02-787 Warszawa, Poland

e-mail: adam_koziol@sggw.pl 